\title{
THE EFFICACY OF SEED PROTECTANTS AGAINST ALTERNARIOSIS DISEASE OF VEGETABLE CROPS
}

\author{
Khalmuminova Gulchehra Kulmuminovna \\ PhD, Senior Teacher of the Department of Agrobiotechnology, Tashkent State Agrarian \\ University, Tashkent, Uzbekistan
}

\begin{abstract}
Khujanazarova Mutabar Kushakovna
Assistant of the Department of Agrobiotechnology, Tashkent State Agrarian University, Tashkent, Uzbekistan
\end{abstract}

\author{
Khamidova Feruza Yusupzhanovna \\ Independent Researcher, Assistant of the Department Storage and Processing of Agricultural \\ Products, Tashkent State Agrarian University, Tashkent, Uzbekistan
}

\begin{abstract}
Vegetable crops make up the bulk of the world's agricultural crops. Currently, the gross yield of vegetables in the world is 560-570 mln. tons, and in developed countries, per capita consumption of vegetables corresponds to 100 kilograms per year. From ancient times, one of the main conditions for ensuring high and quality yields of vegetable crops is the protection of crops from diseases. To meet the needs of the population and industry of the republic, about $1.9 \mathrm{mln}$. tons of potatoes and $5.9 \mathrm{mln}$. tons vegetable and melon products are required. In order to increase the yield and quality of vegetable crops grown in the country, the use of modern technology in their cultivation, the introduction of productive and local varieties, as well as a number of factors play a special role in effective protection of vegetables from various diseases.
\end{abstract}

KEYWORDS: Alternaria, seed protectants, potato seed, tomato seed, disease, pathogen, seed infection.

\section{INTRODUCTION}

Alternariosis diseases of vegetable crops grown in the country have not been studied on a regular basis yet. A.M Muminov, V.I Pestsov and others have studied the occurrence of alternariosis in cabbage, potatoes and tomatoes. In Tashkent region, insufficient research has been conducted on the study of alternariosis in vegetables grown and the development of effective control measures in recent years [13].

Therefore, today, a great attention is paid to conduct thorough research to determine the prevalence and damage of alternariosis in vegetable crops and to study the effect of fungicides against the disease on the yield and quality of vegetable crops.
According to B.A. Khasanov et al, the morphological features of the four informal speciesgroups of small spore representatives of the Alternaria family, most commonly found in food products, including cereals, have given presented below [15].

\section{MATERIALS AND METHODS}

The collection of materials was carried out during a route survey on sowing of agricultural crops in farms and in vegetable stores of Tashkent region.

The identification practices were conducted according to the monographs by M.B. Ellis, L.M. Levkina, F.B. Hannibal $[9,10,6,5]$. Reconciliation was done according to the work of M.Sh. Sagdullaeva et al $[7]$. 


\section{EPRA International Journal of Research and Development (IJRD)}

\section{RESULTS AND DISCUSSION}

One of the research tasks is to test modern and used preparations against alternariosis. As we know, alternariosis diseases have the property of being transmitted by seeds, so the possibilities of spreading diseases by seeds have been studied.

During the study, seed dressing agents recommended and giving good results on the control of fungal diseases and alternariosis were tested. To do this, 1 month before sowing tomato and potato seeds were treated by sprayig with a suspension against fungus Alternaria alternata, and 10 days before sowing the seeds were again sprayed with Raxil 60 FS 6\% WSS (Water soluble suspension) (0.4 and $0.51 / \mathrm{t}$, Topsin $-\mathrm{M}$ $70 \%$ WP (Wettable powder) (1.0 and $1.5 \mathrm{~kg} / \mathrm{t})$, Maxim $2.5 \% \mathrm{SC}$ (Suspension concentrate) $(0.4 \mathrm{l} / \mathrm{t})$, Vitavaks $200 \mathrm{FF} 34 \%$ WSC (Water soluble consentrate) (3.0 and 4.0 1/t), Baraka 60\% P (Paste) (1.0 and $2.0 \mathrm{~kg} / \mathrm{t}$ ); Celest Top 312 FS SC $(0.41 / t)$ and then planted in pots.

A number of experiments were performed to study the effects of the treatment agents within 7 days, 15 days, and 25 days. Based on the experiments conducted, we can say that seed treatment is a highly effective method in disease prevention (Table 1,2).

As can be seen from Table 1, with the effect of seed dressing agent Topsin M 70\% w.p. at a rate of 1.5 $\mathrm{kg} / \mathrm{t}$, high biological efficiency was achieved after 15 days.

When seed dressing agent Topsin M 70\% w.p. was applied against alternariosis in potatoes, $80.3 \%$ biological efficacy was observed after 15 days. It is obvious from Table 2, under the impact of seed dressing agent Vitavax $200 \mathrm{FF} 34 \%$ aq.sus.c., at a rate of $4.0 \mathrm{l} / \mathrm{t}$ , high biological efficiency was achieved after 15 days. When the preparation Vitavaks $200 \mathrm{FF} 34 \%$ aq.sus.c. was used against alternariosis in tomatoes, the biological efficacy was $82.6 \%$ after 15 days.
As far as we know, representatives of the genus Alternaria mainly cause plant leaf spot disease, and under the influence of the disease, the process of photosynthesis in plants is disrupted. As a result, when the plant is severely damaged, it leads to a decrease in yield, which is especially strong in the varieties which are not resistant to diseases.

Literature sources have reported a $78 \%$ decrease in tomato yield in India as a result of alternariosis. Studies in Germany have shown a $50 \%$ decrease in rape yield as a result of alternariosis [8]. Infestation of vegetables with alternariosis reduces the effectiveness of mechanization in harvesting. Representatives of the genus Alternaria are widespread in nature, developing in many plant species, some of them are saprotrophic, many are necrotrophic in parasitic conditions and have different nutritional characteristics and parasitic levels (from facultative parasitic to facultative saprotrophic).

The genus Alternaria representatives have been reported to be abundant in plant seeds. Such damage does not show a specific sign of disease in the seeds. It may not affect seed quantity and quality (1000 seed weight, germination). In some cases, it can adversely affect seed germination and quality [4].

During the development of diseased seeds, the existing fungal species in it reduce seed germination due to the release of toxins, such seed infection in some cases leads to damage and death of seedlings.

Maudy, Humpherson Jones, Evans et al., Coles, Wicks, Vakhrusheva presented data in their works about seed infection of carrot, flax and other farm crops from Brassicaceae family by representatives of the Alternaria genus $[12,11,3]$. Symptoms of alternariosis as a result of seed infection in Brassicaceae family representatives initially appear in the flower peduncle and flower buds, and seed formation may be reduced by $25-80 \%$ [5]. 
SJIF Impact Factor: 7.001| ISI I.F.Value:1.241| Journal DOI: 10.36713/epra2016

ISSN: 2455-7838(Online)

\section{EPRA International Journal of Research and Development (IJRD)}

\section{Table 1}

The efficacy of seed protectant agents against alternariosis in potato plant ("Temir Kadam farm", Kibray district, Tashkent region, 2015)

\begin{tabular}{|c|c|c|c|c|c|c|c|c|c|c|c|c|c|}
\hline \multirow[t]{2}{*}{ Treatments } & \multirow[t]{2}{*}{$\begin{array}{l}\text { Applica- } \\
\text { tion rate, } \\
\text { l/t, kg/t }\end{array}$} & \multirow{2}{*}{$\begin{array}{c}\text { Number } \\
\text { of seed- } \\
\text { lings, } \\
\text { pcs } / \mathrm{m}^{2}\end{array}$} & $\begin{array}{c}\text { Incidence } \\
\text { of diseases, } \\
\text { pieces }\end{array}$ & $\begin{array}{c}\text { Severity of } \\
\text { diseases, } \\
\%\end{array}$ & $\begin{array}{c}\text { Biological } \\
\text { efficiency, } \\
\%\end{array}$ & \multirow[t]{2}{*}{$\begin{array}{c}\text { Number } \\
\text { of seed- } \\
\text { lings, } \\
\text { pcs/m² }\end{array}$} & $\begin{array}{c}\text { Incidence } \\
\text { of } \\
\text { diseases, } \\
\text { pieces }\end{array}$ & $\begin{array}{c}\text { Severity } \\
\text { of } \\
\text { diseases, } \\
\%\end{array}$ & $\begin{array}{c}\text { Biological } \\
\text { efficiency, } \\
\%\end{array}$ & \multirow[t]{2}{*}{$\begin{array}{c}\text { Number } \\
\text { of seed- } \\
\text { lings, } \\
\text { pcs } / \mathbf{m}^{2}\end{array}$} & $\begin{array}{c}\text { Incidence } \\
\text { of } \\
\text { diseases, } \\
\text { pieces }\end{array}$ & $\begin{array}{c}\text { Severity } \\
\text { of } \\
\text { diseases, } \\
\%\end{array}$ & $\begin{array}{c}\text { Biological } \\
\text { efficiency, } \\
\%\end{array}$ \\
\hline & & & \multicolumn{3}{|l|}{7 days } & & \multicolumn{3}{|l|}{15 days } & & \multicolumn{3}{|l|}{25 days } \\
\hline \multirow{2}{*}{$\begin{array}{l}\text { Raxil 60 FS 6\% } \\
\text { WSS }\end{array}$} & 0,4 & 84 & 5 & 6,0 & 69,4 & 76 & 7 & 9,2 & 76,8 & 82 & 8 & 9,8 & 70,0 \\
\hline & 0,5 & 76 & 3 & 3,9 & 72,1 & 78 & 5 & 6,4 & 79,1 & 84 & 7 & 8,3 & 71,3 \\
\hline \multirow{2}{*}{$\begin{array}{l}\text { Topsin-M 70\% } \\
\text { WP }\end{array}$} & 1,0 & 87 & 6 & 6,9 & 68,1 & 79 & 5 & 6,3 & 79,1 & 82 & 8 & 9,8 & 70,0 \\
\hline & 1,5 & 86 & 4 & 4,7 & 70,7 & 84 & 4 & 4,8 & 80,3 & 77 & 7 & 9,1 & 71,3 \\
\hline $\begin{array}{l}\text { Maxim 2.5\% SC } \\
\text { (standard) }\end{array}$ & 0,4 & 88 & 5 & 5,7 & 69,4 & 78 & 6 & 7,7 & 77,9 & 84 & 9 & 10,7 & 68,8 \\
\hline $\begin{array}{l}\text { Not treated } \\
\text { control }\end{array}$ & - & 76 & 68 & 89,5 & - & 85 & 71 & 83,5 & - & 80 & 74 & 92,5 & - \\
\hline $\mathrm{LSD}_{05}=$ & & & & 1,7 & & & & 1,9 & & & & 1,1 & \\
\hline
\end{tabular}

Table 2

The efficacy of seed protectant agents against alternariosis in tomato plant ("Nosirov Abdiraym" farm, Kibray district, Tashkent region, 2015)

\begin{tabular}{|c|c|c|c|c|c|c|c|c|c|c|c|c|c|}
\hline \multirow[t]{2}{*}{$\begin{array}{l}\text { Experiment } \\
\text { options }\end{array}$} & \multirow[t]{2}{*}{$\begin{array}{l}\text { Applica- } \\
\text { tion } \\
\text { rate, } 1 / \mathrm{t} \text {, } \\
\mathrm{kg} / \mathrm{t}\end{array}$} & \multirow[t]{2}{*}{$\begin{array}{l}\text { Number } \\
\text { of seed- } \\
\text { lings, } \\
\text { pcs } / \text { m }^{2}\end{array}$} & $\begin{array}{l}\text { Incidence } \\
\text { of diseases, } \\
\text { pieces }\end{array}$ & $\begin{array}{l}\text { Severity of } \\
\text { diseases, } \\
\%\end{array}$ & $\begin{array}{l}\text { Biological } \\
\text { efficiency, } \\
\%\end{array}$ & \multirow[t]{2}{*}{$\begin{array}{l}\text { Number } \\
\text { of seed- } \\
\text { lings, } \\
\text { pcs } / \text { m² }^{2}\end{array}$} & $\begin{array}{l}\text { Incidence } \\
\text { of } \\
\text { diseases, } \\
\text { pieces }\end{array}$ & $\begin{array}{l}\text { Severity } \\
\text { of } \\
\text { diseases, } \\
\%\end{array}$ & $\begin{array}{l}\text { Biological } \\
\text { efficiency, } \\
\%\end{array}$ & \multirow[t]{2}{*}{$\begin{array}{l}\text { Number } \\
\text { of seed- } \\
\text { lings, } \\
\text { pcs } / \text { m }^{2}\end{array}$} & $\begin{array}{l}\text { Incidence } \\
\text { of } \\
\text { diseases, } \\
\text { pieces }\end{array}$ & $\begin{array}{l}\text { Severity } \\
\text { of } \\
\text { diseases, } \\
\%\end{array}$ & $\begin{array}{l}\text { Biological } \\
\text { efficiency, } \\
\%\end{array}$ \\
\hline & & & \multicolumn{3}{|l|}{7 days } & & \multicolumn{3}{|l|}{15 days } & & \multicolumn{3}{|l|}{25 days } \\
\hline \multirow{2}{*}{$\begin{array}{l}\text { Vitavaks } 200 \mathrm{FF} \\
\text { 34\% WSC } \\
\end{array}$} & 3,0 & 86 & 8 & 9,3 & 73,4 & 78 & 3 & 3,8 & 81,5 & 84 & 6 & 7,1 & 73,6 \\
\hline & 4,0 & 83 & 8 & 9,6 & 73,4 & 79 & 2 & 2,5 & 82,6 & 74 & 6 & 8,1 & 73,6 \\
\hline \multirow{2}{*}{ Baraka $60 \% \mathrm{P}$} & 1,0 & 85 & 10 & 11,8 & 71,0 & 84 & 7 & 8,3 & 76,8 & 81 & 11 & 13,6 & 67,4 \\
\hline & 2,0 & 82 & 11 & 13,4 & 69,7 & 86 & 7 & 8,1 & 76,8 & 83 & 10 & 12,0 & 68,7 \\
\hline Not treated control & - & 83 & 71 & 85,5 & - & 85 & 69 & 81,2 & - & 81 & 73 & 90,1 & - \\
\hline$L^{\prime S D_{05}}=$ & & & & 1,7 & & & & 1,9 & & & & 1,1 & \\
\hline
\end{tabular}




\section{EPRA International Journal of Research and Development (IJRD)}

According to Ya. Van der Plank, it is important to achieve a reduction in the population by reducing the source of the initial infection or slowing the rate of disease development in the prevention of the diseases [1].

Based on this, D.A.Roberts stated that it is important to plan protective measures considering the criteria of economic damage based on the stage of development of the disease [14].

In this regard, experts say that firstly, phytosanitary measures can reduce the sources of infection, i.e ensuring nonoccurrence of development of the pathogen during the growing season, and secondly, limiting the growth of pathogens during the growing season, for example, the use of protective fungicides.

\section{CONCLUSION}

When the preparation Vitavax $200 \mathrm{FF} 34 \%$ WSC from seed dressing agents was applied at a rate of $4.0 \mathrm{l} / \mathrm{t}$ against tomato alternariosis, it showed a biological efficiency of $82.6 \%$.

At the application of seed dressing agent Topsin M $70 \% \mathrm{WP}$ at a consumption rate of $1.5 \mathrm{~kg} / \mathrm{t}$ against potato alternariosis, it showed a biological efficiency of $80.3 \%$.

Before sowing vegetable crops, the seed dressing with the application of preparations Vitavaks $200 \mathrm{FF}$ $34 \% \mathrm{WSC}$ at a rate of $4.0 \mathrm{1} / \mathrm{t}$ or Topsin M 70\% WP at a rate of $1.5 \mathrm{~kg} / \mathrm{t}$ is recommended against alternariosis diseases.

\section{REFERENCES}

1. Van der Plank. Ya.E. Plant diseases (Epiphytoties and the fight against them). - Moscow: Kolos, 1966. p.359.

2. Vakhrusheva T.E.. About black rot of carrots. Protection of plants from pests and diseases. - Leningrad: Pushkin, 1973.-pp. 74-76.

3. Coles R.B., Wicks T.J. The Incidence of Alternariaradicina on carrot seeds seedlings and roots in south Australia. Australasian plants pathol, 2003. pp. 95104.

4. Hannibal F.B., Gasich E.L. Alternaria pathogens on the plants of cruciferous family in Russia: species composition, geography and ecology. Mycology and phytopathology, 2009, 43, 5, pp. 79-88.

5. Hannibal F.B. Monitoring of Alternaria diseases of agricultural crops and identification of fungi of the genus Alternaria. - SPb., 2011, $71 \mathrm{p}$.

6. Levkina L.M. Taxonomy of the genus Alternaria Nees. Mycology and phytopathology. 1984. edit. 18. № 1. pp. 80-86.

7. Sagdullayeva M.Sh., Kirgizbayeva H.M., Ramazanova S.S. et al. Hyphal fungi. Flora of fungi in Uzbekistan, v.6 - Tashkent, Fan, 1990. 132 p.

8. Datar V.V, Mayee C.D. Assessment of losses in tomato yield due to early blight. Indian Phytopathol., 1981, 34, p. 191-195.

9. Ellis M.B. Dematiaceous hyphomycetes - Kew, Surrey, UK, CMI, 1971. 608 p.

10. Ellis M.B. More dematiaceous hyphomycetes - Kew, Surrey, UK, CAB IMI, 1976. 507 p.
11. Evans N., Mc. Roberts N., Hill R.A., Marshall G.I. Phytotoxin production by Alternaria linicola and phytoalexin production by the linseed host. Ann. Appl. Biol., 1996. pp. 415-431.

12. Maude R.B., Humpherson-Jones F.M. Studies on the seed-born phases of dark leaf spot (Alternaria brassicola) and gray leaf spot (Alternaria brassicae) of brassicas // Ann. Appl. Biol, 1980. pp.311-319.

13. Muminov A.M., Pestsov V.I. and others. Directory on vegetable growing, melons and potatoes. Tashkent: Mehnat, 1986.

14. Roberts D.A. Plant protection basics. Moscow: Kolos, 1981. 254 p.

15. Khasanov B.A., Turdieva D.T., Sherimbetov A.G. Modern taxonomy of wheat alternariosis and Alternaria family. Monograph. Tashkent., TashSAU, 2019. 120 p. 